\title{
Influence of biostimulants on phenolic content in broccoli heads directly after harvest and after storage
}

\author{
Alina Kałużewicz ${ }^{1 *}$, Monika Gąsecka ${ }^{2}$,Tomasz Spiżewski ${ }^{1}$ \\ ${ }^{1}$ Department of Vegetable Crops \\ Poznań University of Life Sciences \\ Dąbrowskiego 159, 60-594 Poznań, Poland \\ ${ }^{2}$ Research Unit of Analytical Chemistry \\ Poznań University of Life Sciences \\ Wojska Polskiego 25, 60-625 Poznań, Poland
}

\begin{abstract}
Biostimulants are commonly used in horticulture, primarily to increase yield quantity and quality, as well as plant tolerance to stress. The purpose of the study was to determine the effect of amino acid-based biostimulants and amino acids in combination with Ascophyllum nodosum filtrate, applied during the growing season on the phenolic content in broccoli heads both after harvest and after long storage in a cold store. The seedlings were planted in mid-July, and heads were harvested from September to October in each year of the study. Ascophyllum nodosum filtrate at a concentration of $1 \%$ was used during seedling production. The plants were watered with biostimulants twice, in the fourth and fifth week after sowing. They were also sprayed with amino acid-based biostimulants $\left(1.5 \mathrm{dm}^{3} \mathrm{ha}^{-1}\right)$ three times, i.e. after the second, fourth and sixth week after planting. The biostimulants were not used in the control treatment. After harvest, the heads were stored for three weeks in a cold store at $1-2^{\circ} \mathrm{C}$ and $95 \% \mathrm{RH}$. Chemical analyses of total phenolic, caffeic, ferulic and sinapic acids, and of quercetin and kaempferol were carried out on samples of fresh broccoli and after the first, second and third week of storage. It was found that the application of biostimulants resulted in a significant increase in the total phenolic content, sinapic acid content, as well as quercetin content. Both in the control treatment and in the plants treated with the biostimulants, the concentration of all the tested phenolic compounds increased with the duration of storage.
\end{abstract}

Key words: amino acids, Ascophyllum nodosum filtrate, Brassica oleracea var. italica, kaempferol, phenolic acids, quercetin

\section{INTRODUCTION}

Biostimulants based on amino acids and marine algae have been applied in horticulture for many years. Amino acid-based biostimulants are produced by the chemical and enzymatic hydrolysis of proteins of both plant and animal origin (du Jardin 2015). Ascophyllum nodosum is one of the 2000 species of brown algae and is used for the production of biostimulants (Ugarte et al. 2006, Hong et al. 2007). One of the main components of seaweed extracts are polysaccharides, which account for $30-40 \%$ of the dry matter (Rayorath et al. 2009). In addition, seaweed extracts are a rich source of phytohormones such as auxins, cytokinins, gibberellins, abscisic acid and brassinosteroids (Stirk et al. 2014), and

\footnotetext{
*Corresponding author.

Tel.: +48 618487966 ;

e-mail: alina.kaluzewicz@up.poznan.pl (A. Kałużewicz). 
polyphenol compounds (Holdt and Kraan 2011). Because of the antioxidant content, they enhance the resistance of plants to stress (Ertani et al. 2011).

The use of biostimulants based on amino acids and combinations of amino acids with seaweed extracts improves the uptake of nutrients from the soil by plants (Zodape et al. 2011, Nardi et al. 2016, Szczepanek and Grzybowski 2016), improves sprouting (Carvalho et al. 2013), enhances vegetative growth (Zhang and Hamauzu 2003), increases the chlorophyll content (Thirumaran et al. 2009), as well as yield quality and quantity (Kowalczyk et al. 2008, Shehata et al. 2011, Grabowska et al. 2015). The use of seaweed extracts resulted in an increase in vitamin $\mathrm{C}$ in Chinese cabbage (Gajewski et al. 2008) and in tomato fruits (Dobromilska and Gubarewicz 2008). In addition, the use of both amino acids and seaweed extracts resulted in an increase in the sugar content in celery (Shehata et al. 2011) and in the levels of phenolic and flavonoid compounds in broccoli and cabbage (Lola-Luz 2013, 2014).

Maintaining good quality of harvested vegetables over a long period of time can be achieved by appropriate post-treatment and storage conditions (Badełek et al. 2013). The notion of good quality refers not only to the preservation of the colour of the cultivar and its turgor, but also to its chemical composition. It is very beneficial to maintain an adequate level of antioxidants, including phenolic compounds, which are important for human health. Flavonoids are considered to be protective against cardiovascular diseases by decreasing thrombocytes and strengthening the walls of blood capillaries (Prior and Cao 2000), and have a significant positive influence on the anticarcinogenic properties of broccoli (Podsędek 2007).

Many studies have confirmed the effects of storage duration and conditions on the quality of broccoli heads (Starzyńska et al. 2003, Hasperué et al. 2015, Vale et al. 2015). According to Balouchi et al. (2011), of the five broccoli cultivars compared in their study, after 40 days of storage at $0^{\circ} \mathrm{C}$, four cultivars exhibited a significant increase in phenolic content, while a fall was observed in one of the cultivars. However, the flavanoid content decreased considerably in all the cultivars. In a study by Hasperué et al. (2015), after 2 and 3 weeks of storage at $4^{\circ} \mathrm{C}$, a significant decrease in total phenols was observed in primary broccoli heads, while in secondary heads the content increased, especially after the third week. A change in hydroxycinnamic acids content during storage at $4^{\circ} \mathrm{C}$ was reported by Vale et al. (2015). According to the authors, the level of the acids increased until the fifth day of storage, and then it decreased to the lowest value after 12 days. In the research by Starzyńska et al. (2003), when broccoli heads were stored at $5^{\circ} \mathrm{C}$ there was a significant increase in the concentration of phenolic compounds after 7 and 10 days, both in the heads packed in commercial polymeric film and in non-packed heads. The factors considerably affecting both the phenolic and flavonoid contents were: controlled atmosphere of storage $\left(1-2^{\circ} \mathrm{C}\right.$, $85-90 \% \mathrm{RH}, 10 \% \mathrm{O}_{2}$ and $5 \% \mathrm{CO}_{2}$ ) (FernandezLeón et al. 2013), cultivation conditions - organic or conventional (Valverde et al. 2015), and fertilization (Vallejo et al. 2003). According to some authors, application of biostimulants leads to an increase in the levels of phenolic compounds in the edible plant parts (Lola-Luz et al. 2013, Ertani et al. 2014). Most of the described studies, however, discuss their concentrations immediately after harvest (Lola-Luz et al. 2014). However, the research on the effects of biostimulants on the levels of phenolic compounds in vegetables during storage has been very limited.

The aim of the study was to determine if amino acid-based biostimulants and amino acids in combination with Ascophyllum nodosum filtrate, applied during the growing season, caused an increase in the phenolic content in broccoli heads immediately after harvest and after the first, second and third week of storage in a cold store $\left(1-2^{\circ} \mathrm{C}\right.$, $95 \% \mathrm{RH})$.

\section{MATERIAL AND METHODS}

\section{Plant material}

The experiment was conducted in 2012-2013. The study comprised one cultivar of broccoli 'Tiburon'. Broccoli seedlings were produced in cell trays of $54 \mathrm{~cm}^{3}$ capacity, filled with peat substrate for cruciferous vegetables. The transplants were planted out in the field in the middle of July. Thirtyfive transplants were planted. The experiment was established on a podzolic soil, the arable layer of which was loamy sand underlying sandy loam. The soil was tested before planting and a compound fertilizer was applied before soil preparation. Additionally, nitrogen $\left(150 \mathrm{~kg} \mathrm{ha}^{-1}\right)$ was applied in three doses during the growing season. The plants were cultivated without watering. The experiment was established in a randomized block design with four replications. The experimental treatments were as follows: amino acid-based biostimulant 
(AA) - $1.5 \mathrm{dm}^{3} \mathrm{ha}^{-1}$ (plants were sprayed 2, 4, and 6 weeks after planting), Ascophyllum nodosum filtrate (AN) - 1\% (seedlings were watered 4 and 5 weeks after sowing) $+\mathrm{AA}-1.5 \mathrm{dm}^{3} \mathrm{ha}^{-1}$ (plants were sprayed 2, 4, and 6 weeks after planting), control plants (without biostimulants). The amino acid-based biostimulant contained 18 amino acids, both in free form and as short peptide chains. The Ascophyllum nodosum filtrate was enriched with phosphorus $\left(13 \% \mathrm{P}_{2} \mathrm{O}_{5}\right)$ and potassium $\left(5 \% \mathrm{~K}_{2} \mathrm{O}\right)$.

Broccoli heads were harvested from September to October in each year of the study. Twenty-four evenly compact and sized heads were collected from each treatment. After harvesting 6 heads from each experimental combination, two samples were taken, 50 grams each, and frozen at $-20^{\circ} \mathrm{C}$. The remaining heads from each treatment were placed in three boxes, 6 heads in each box. The heads were stored in a dark cold store $\left(1-2^{\circ} \mathrm{C}, 95 \% \mathrm{RH}\right)$ for 1,2 and 3 weeks. After each week of storage, samples were taken and frozen in the same way as for the unstored heads.

\section{Analysis of phenolic compounds}

The phenolics were extracted from the frozen broccoli heads that had been homogenized in $80 \%$ methanol according to Gąsecka et al. (2015) with some modifications ( $8 \mathrm{~g}$ of broccoli were mixed with $10 \mathrm{ml}$ of $80 \%$ methanol, stirred and shaken for $2 \mathrm{~h}$ ). The total phenolic content was determined according to Singleton and Rossi (1965) using the Folin-Ciocalteu assay, with gallic acid used as a standard. The absorbance of extracts was measured at $\lambda=765 \mathrm{~nm}$ using a Varian Cary 300 Bio UV-Visible spectrophotometer.

The concentration of phenolic acids (caffeic, ferulic, and sinapic) and flavonoids (quercetin and kaempferol) was determined after alkaline and acid hydrolysis according to Gliszczyńska-Świgło et al. (2007) with some modifications. The samples were treated with $2 \mathrm{M} \mathrm{NaOH}$ and boiled for 30 minutes. After acidification, the phenolics were extracted with diethyl ether. Then, the methanolic extracts were treated with $6 \mathrm{M} \mathrm{HCl}$, boiled for 30 minutes, and extracted with diethyl ether. The extracts were combined and dried. Before being injected into the HPLC column the extracts were re-dissolved in $1 \mathrm{ml}$ of $80 \%$ ethanol .

The HPLC analysis was performed with a Waters Alliance 2695 Chromatograph coupled with a Waters 2996 Photodiode Array Detector, as described earlier (Borowiak et al. 2015). Chromatographic separation was carried out on an RP C-18 column, $250 \times 4 \mathrm{~mm} \times 5 \mu \mathrm{m}$ (at a temperature of $20^{\circ} \mathrm{C}$ ). The mobile phase consisted of $\mathrm{A}$ - acetonitrile, and $\mathrm{B}-$ water and $2 \%$ acetic acid $(\mathrm{pH}=2)$. The gradient elution was as follows: at the start $-100 \% \mathrm{~B} ; 0-14 \mathrm{~min}-90 \% \mathrm{~B} ; 14-30$ $\min -90 \% \mathrm{~B} ; 30-45 \min -82 \% \mathrm{~B} ; 45-55 \min -$ $100 \%$ A; $55-60 \min -100 \%$ A; $60-75 \min -100 \%$ B. The concentrations of phenolic compounds were determined by means of an internal standard at wavelengths of $\lambda=280 \mathrm{~nm}$ (caffeic and sinapic acids) or $\lambda=320 \mathrm{~nm}$, and $280 \mathrm{~nm}$ (ferulic acid), or $\lambda=320 \mathrm{~nm}$ (flavonoids). The compounds were identified by comparing the retention time of the peak under analysis with the retention time of the standard, and by adding a specific amount of the standard to the samples analysed, as well as by repeating the analysis. The retention times of the assayed acids and flavonoids were as follows: caffeic acid - $26.19 \mathrm{~min}$; ferulic acid $-46.20 \mathrm{~min}$; sinapic acid - $48.00 \mathrm{~min}$; quercetin $-52.25 \mathrm{~min}$; and kaempferol - $53.13 \mathrm{~min}$. The detection level was $1 \mu \mathrm{g} \mathrm{g}^{-1}$. The caffeic, ferulic, and sinapic acids, quercetin, kaempferol, Folin-Ciocalteu's phenol reagent, sodium carbonate and $\mathrm{NaOH}$ were purchased from Sigma Aldrich (St. Louis, MO, USA). The diethyl ether was purchased from Honeywell (Germany). Methanol (HPLC super gradient, 99.9\%), acetonitrile (for HPLC, 99.9\%) were purchased from POCH S.A Gliwice, Poland.

\section{Statistical analysis}

All statistical analyses were performed using the Statistica software (StatSoft, Poland). The significance of the impact of the biostimulants and the duration of storage on the concentration of phenolic compounds was determined with the F-test. The differences among the mean values were estimated with the Duncan test, with the level of significance at $p<0.05$.

\section{RESULTS AND DISCUSSION}

Large differences in the total phenolic content in fresh broccoli heads were found between the two years of the study (Tab. 3). In the second year, it was, on average, more than 3 times higher than in the first year. Valverde et al. (2015), too, had noted that the differences in total phenolic content between successive years of study were almost fourfold. According to Vallejo et al. (2003) and GliszczyńskaŚwigło et al. (2007), the phenolic content depends on the weather conditions during the vegetation period. Mølmann et al. (2015) reported higher levels of quercetin and kaempferol at $18^{\circ} \mathrm{C}$ than at $12^{\circ} \mathrm{C}$. 
Table 1. Temperature and total rainfall in the period of broccoli cultivation

\begin{tabular}{lccrr}
\hline \multirow{2}{*}{ Year } & \multicolumn{3}{c}{ Temperature $\left({ }^{\circ} \mathrm{C}\right)$} & Total rainfall (mm) \\
\cline { 2 - 4 } & Maximum & Minimum & Daily & \\
\cline { 2 - 4 } & \multicolumn{4}{c}{ From planting to harvest } \\
\hline 2012 & 24.0 & 13.1 & 18.3 & 68.0 \\
2013 & 20.7 & 10.6 & 15.7 & 143.8 \\
\hline & \multicolumn{2}{c}{30 days before harvest } & 19.0 \\
2012 & 24.0 & 12.6 & 18.3 & 21.0 \\
\hline
\end{tabular}

Table 2. ANOVA F-values for the total phenolics, phenolic acids and flavonol content

\begin{tabular}{lcccccc}
\hline \multirow{2}{*}{ Object } & Total & \multicolumn{3}{c}{ Phenolic acids } & \multicolumn{2}{c}{ Flavonols } \\
\cline { 3 - 7 } & phenolics & Caffeic & Ferulic & Sinapic & Quercetin & Kaempferol \\
\hline Week & & & & 2012 & $* *$ & $* *$ \\
Biostimulant & $* *$ & $* *$ & $\mathrm{~ns}$ & $* *$ & $* *$ & $* *$ \\
Week $\times$ biostimulant & $* *$ & $* *$ & $* *$ & $\mathrm{~ns}$ & $* *$ & $* *$ \\
\hline Week & & & $* *$ & 2013 & & $* *$ \\
Biostimulant & $*$ & $\mathrm{~ns}$ & $\mathrm{~ns}$ & $*$ & $* *$ & $*$ \\
Week $\times$ biostimulant & $\mathrm{ns}$ & $\mathrm{ns}$ & $\mathrm{ns}$ & $\mathrm{ns}$ & $\mathrm{ns}$ & $\mathrm{ns}$ \\
\hline
\end{tabular}

* - significance level at $p<0.1, * *$ - significance level at $p<0.05$, ns - not significant at $p<0.05$

Table 3. Total phenolics in broccoli heads

\begin{tabular}{|c|c|c|c|c|c|}
\hline \multirow{3}{*}{ Treatment } & \multicolumn{5}{|c|}{ Week of storage } \\
\hline & Fresh & 1 & 2 & 3 & Mean \\
\hline & \multicolumn{5}{|c|}{ Total phenolics (mg GAE $100 \mathrm{~g}^{-1} \mathrm{FW}$ ) } \\
\hline & \multicolumn{5}{|c|}{2012} \\
\hline $\mathrm{C}$ & $2.75 \mathrm{~h}^{*}$ & $6.06 \mathrm{~g}$ & $7.45 \mathrm{ef}$ & $10.16 \mathrm{c}$ & $6.60 \mathrm{C}$ \\
\hline $\mathrm{AA}+\mathrm{AN}$ & $2.64 \mathrm{~h}$ & $6.93 \mathrm{fg}$ & $9.11 \mathrm{~d}$ & $11.82 \mathrm{~b}$ & $7.62 \mathrm{~B}$ \\
\hline AA & $3.43 \mathrm{~h}$ & $8.19 \mathrm{e}$ & $10.27 \mathrm{c}$ & $14.55 \mathrm{a}$ & $9.11 \mathrm{~A}$ \\
\hline \multirow[t]{2}{*}{ Mean } & $2.94 \mathrm{D}^{* *}$ & $7.06 \mathrm{C}$ & $8.94 \mathrm{~B}$ & $12.18 \mathrm{~A}$ & \\
\hline & \multicolumn{5}{|c|}{2013} \\
\hline $\mathrm{C}$ & $8.46 \mathrm{~g}$ & 11.54 ef & $12.68 \mathrm{e}$ & $16.16 \mathrm{bc}$ & $12.14 \mathrm{C}$ \\
\hline $\mathrm{AA}+\mathrm{AN}$ & $10.35 \mathrm{f}$ & $13.42 \mathrm{de}$ & $15.06 \mathrm{~cd}$ & $18.14 \mathrm{~b}$ & $14.24 \mathrm{~B}$ \\
\hline AA & $11.66 \mathrm{ef}$ & $16.53 \mathrm{bc}$ & $14.91 \mathrm{~cd}$ & $21.19 \mathrm{a}$ & $16.07 \mathrm{~A}$ \\
\hline Mean & $10.07 \mathrm{C}$ & $13.83 \mathrm{~B}$ & $14.21 \mathrm{~B}$ & $18.49 \mathrm{~A}$ & \\
\hline
\end{tabular}

C - control, AA - amino acids, AN - Ascophyllum nodosum filtrate

*Values marked with the same letter in each column do not differ significantly at $p<0.05$

**Values marked with the same capital letter do not differ significantly at $p<0.05$

A similar tendency was noted by Kałużewicz et al. (2012) in a study where a higher flavonol content was obtained in the year that was characterized by higher temperatures, especially during the 30 days prior to harvest. According to Klimov et al. (2008), the increased level of flavonoids at higher temperatures is associated with higher quantities of reactive oxygen species (ROS). However, the opposite trend was observed in our own study. The higher total phenolic content was accompanied by lower temperatures during the growing period (Tabs 1 and 3).

In the present study, the biostimulants had a significant positive influence on the total phenolic content (Tabs 2 and 3). The significant effect of Ascophyllum nodosum extract on the amounts of 
phenolic compounds in broccoli heads and spinach leaves had also been confirmed by the studies by Fan et al. (2011) and Lola-Luz (2014). According to Fan et al. (2013), the increase in the phenolic content in spinach treated with an Ascophyllum nodosum extract could be related to an increase in the levels of endogenous plant hormones whose activity was stimulated by the biostimulant. Elansary et al. (2016) also reported that the use of seaweed extracts increased the total phenolic content and the amounts of flavonoids, which in turn was associated with an increased antioxidant and lipid peroxidation activity.

In our study, the increase in phenolic content after the AA treatment was consistent with the findings of Gurav and Jadhav (2013).

In all the experimental combinations, the total phenolic content increased with the duration of storage (Tab. 3). Generally, the total phenolic content was higher in the heads obtained from plants treated with the biostimulants than from the control plants. The increase in phenolic content after harvest may be due to the response of plants to harvesting as an abiotic stress, which is related to plant wounding and plant's inability to extract water and minerals.

Wounded plants produce reactive oxygen species, which activate the primary and secondary metabolism. In addition, the injured plants produce ethylene and jasmonic acid, which affect the level of ROS and thereby influence the expression of secondary metabolism genes. As a result, accumulation of secondary metabolites can be observed (Jacobo-Velázquez et al. 2015). Ertani et al. (2013) had demonstrated that the use of biostimulants based on a protein hydrolyzate in corn plants subjected to salt stress stimulated the enzymes involved in nitrogen metabolism, increased phenylalanine ammonia-lyase (PAL) activity and the synthesis of flavonoids. PAL is an enzyme which is involved in the synthesis of phenols. Phenylalanine is converted to transcinnamic acid and tyrosine to p-carboxylic acid (Ertani at al. 2011).

Table 4. Quercetin and kaempferol in broccoli heads

\begin{tabular}{|c|c|c|c|c|c|}
\hline \multirow{3}{*}{ Treatment } & \multicolumn{5}{|c|}{ Week of storage } \\
\hline & Fresh & 1 & 2 & 3 & Mean \\
\hline & \multicolumn{5}{|c|}{ Quercetin (mg $\left.100 \mathrm{~g}^{-1} \mathrm{FW}\right)$} \\
\hline & \multicolumn{5}{|c|}{2012} \\
\hline $\mathrm{C}$ & $1.382 \mathrm{e}^{*}$ & $1.582 \mathrm{~d}$ & $2.495 \mathrm{a}$ & $2.354 \mathrm{ab}$ & $1.953 \mathrm{~B}$ \\
\hline $\mathrm{AA}+\mathrm{AN}$ & $1.245 \mathrm{e}$ & $1.704 \mathrm{~d}$ & $1.977 \mathrm{c}$ & $2.502 \mathrm{a}$ & $1.857 \mathrm{C}$ \\
\hline $\mathrm{AA}$ & $1.346 \mathrm{e}$ & $2.187 \mathrm{~b}$ & $2.304 \mathrm{ab}$ & $2.455 \mathrm{a}$ & $2.073 \mathrm{~A}$ \\
\hline \multirow[t]{2}{*}{ Mean } & $1.324 \mathrm{D}$ & $1.824 \mathrm{C}$ & $2.259 \mathrm{~B}$ & $2.437 \mathrm{~A}$ & \\
\hline & \multicolumn{5}{|c|}{2013} \\
\hline $\mathrm{C}$ & $1.280 \mathrm{~d}$ & $1.620 \mathrm{bc}$ & $1.799 \mathrm{~b}$ & $2.098 \mathrm{a}$ & $1.699 \mathrm{~B}$ \\
\hline $\mathrm{AA}+\mathrm{AN}$ & $1.491 \mathrm{~cd}$ & $1.589 \mathrm{bc}$ & $2.055 \mathrm{a}$ & $2.054 \mathrm{a}$ & $1.797 \mathrm{AB}$ \\
\hline $\mathrm{AA}$ & $1.524 \mathrm{c}$ & $1.543 \mathrm{c}$ & $2.099 \mathrm{a}$ & $2.241 \mathrm{a}$ & $1.852 \mathrm{~A}$ \\
\hline \multirow[t]{3}{*}{ Mean } & $1.431 \mathrm{D}$ & $1.584 \mathrm{C}$ & $1.984 \mathrm{~B}$ & $2.131 \mathrm{~A}$ & \\
\hline & \multicolumn{5}{|c|}{ Kaempferol $\left(\mathrm{mg} 100 \mathrm{~g}^{-1} \mathrm{FW}\right)$} \\
\hline & \multicolumn{5}{|c|}{2012} \\
\hline $\mathrm{C}$ & $5.826 \mathrm{e}-\mathrm{g}$ & $7.001 \mathrm{a}$ & $7.138 \mathrm{a}$ & $7.056 \mathrm{a}$ & $6.755 \mathrm{~A}$ \\
\hline $\mathrm{AA}+\mathrm{AN}$ & $5.744 \mathrm{fg}$ & $5.937 \mathrm{~d}-\mathrm{f}$ & $6.203 \mathrm{~cd}$ & $6.660 \mathrm{~b}$ & $6.136 \mathrm{~B}$ \\
\hline AA & $6.149 \mathrm{de}$ & $5.551 \mathrm{~g}$ & $6.512 \mathrm{bc}$ & $6.598 \mathrm{~b}$ & $6.202 \mathrm{~B}$ \\
\hline \multirow[t]{2}{*}{ Mean } & $5.906 \mathrm{C}^{* *}$ & $6.163 \mathrm{~B}$ & $6.617 \mathrm{~A}$ & $6.771 \mathrm{~A}$ & \\
\hline & \multicolumn{5}{|c|}{2013} \\
\hline $\mathrm{C}$ & $6.428 \mathrm{c}$ & $6.741 \mathrm{c}$ & $8.057 \mathrm{~b}$ & $8.651 \mathrm{ab}$ & $7.469 \mathrm{~B}$ \\
\hline $\mathrm{AA}+\mathrm{AN}$ & $6.341 \mathrm{c}$ & $6.451 \mathrm{c}$ & $8.458 \mathrm{ab}$ & $8.571 \mathrm{ab}$ & $7.455 \mathrm{~B}$ \\
\hline $\mathrm{AA}$ & $6.752 \mathrm{c}$ & $6.583 \mathrm{c}$ & $9.165 \mathrm{a}$ & $8.835 \mathrm{a}$ & $8.018 \mathrm{~A}$ \\
\hline Mean & $6.507 \mathrm{~B}$ & $6.591 \mathrm{~B}$ & $8.560 \mathrm{~A}$ & $8.685 \mathrm{~A}$ & \\
\hline
\end{tabular}

$\mathrm{C}$ - control, AA - amino acids, AN - Ascophyllum nodosum filtrate

$*$ Values marked with the same letter in each column do not differ significantly at $p<0.05$

$* *$ Values marked with the same capital letter do not differ significantly at $p<0.05$ 
Moreover, Ascophyllum nodosum contains osmolytes, such as mannitol (Reed et al. 1985). An increase in the concentration of phenolic compounds could be due to the osmotic stress caused by mannitol (Guo et al. 2011).

The increase in the total phenolic content with the duration of storage is consistent with the findings of Leja et al. (2001). Those authors reported a nearly $27 \%$ increase in phenolic content after a week of storage at $5^{\circ} \mathrm{C}$. Serrano et al. (2006) and Fernández-
León et al. (2013) obtained the opposite results. They observed that during storage at $1-2^{\circ} \mathrm{C}$ the total phenolic content gradually decreased with the duration of storage. In the experiment by FernándezLeón et al. (2013), after 3 weeks of storage, the total phenolic content was only $66 \%$ of the amount in fresh broccoli heads. Conversa et al. (2013) found that changes in the level of phenolic compounds depended on the cultivar. After 14 days of storage at $5^{\circ} \mathrm{C}$, a significant increase had occurred in

Table 5. Phenolic acids in broccoli heads

\begin{tabular}{|c|c|c|c|c|c|}
\hline \multirow{3}{*}{ Treatment } & \multicolumn{5}{|c|}{ Week of storage } \\
\hline & Fresh & 1 & 2 & 3 & Mean \\
\hline & \multicolumn{5}{|c|}{ Caffeic acid (mg $\left.100 \mathrm{~g}^{-1} \mathrm{FW}\right)$} \\
\hline & \multicolumn{5}{|c|}{2012} \\
\hline $\mathrm{C}$ & $1.103 \mathrm{~g}^{*}$ & $1.793 \mathrm{e}$ & $2.395 \mathrm{c}$ & $2.601 \mathrm{~b}$ & $1.973 \mathrm{C}$ \\
\hline $\mathrm{AA}+\mathrm{AN}$ & $1.096 \mathrm{~g}$ & $1.910 \mathrm{e}$ & $2.444 \mathrm{c}$ & $3.500 \mathrm{a}$ & $2.238 \mathrm{~B}$ \\
\hline $\mathrm{AA}$ & $1.308 \mathrm{f}$ & $2.240 \mathrm{~d}$ & $2.704 \mathrm{f}$ & $3.455 \mathrm{a}$ & $2.427 \mathrm{~A}$ \\
\hline \multirow[t]{2}{*}{ Mean } & $1.169 \mathrm{D}^{* *}$ & $1.981 \mathrm{C}$ & $2.514 \mathrm{~B}$ & $3.185 \mathrm{~A}$ & \\
\hline & \multicolumn{5}{|c|}{2013} \\
\hline $\mathrm{C}$ & $1.881 \mathrm{e}$ & $2.410 \mathrm{~cd}$ & $2.547 \mathrm{~cd}$ & $3.648 \mathrm{a}$ & $2.621 \mathrm{~B}$ \\
\hline $\mathrm{AA}+\mathrm{AN}$ & $2.059 \mathrm{de}$ & $2.761 \mathrm{~cd}$ & $2.818 \mathrm{~b}$ & $3.601 \mathrm{a}$ & $2.809 \mathrm{~A}$ \\
\hline $\mathrm{AA}$ & $2.081 \mathrm{de}$ & $2.639 \mathrm{~cd}$ & $2.710 \mathrm{~cd}$ & $3.339 \mathrm{a}$ & $2.692 \mathrm{AB}$ \\
\hline \multirow[t]{3}{*}{ Mean } & $2.007 \mathrm{C}$ & $2.603 \mathrm{~B}$ & $2.691 \mathrm{~B}$ & $3.529 \mathrm{~A}$ & \\
\hline & \multicolumn{5}{|c|}{ Ferulic acid $\left(\mathrm{mg} 100 \mathrm{~g}^{-1} \mathrm{FW}\right)$} \\
\hline & \multicolumn{5}{|c|}{2012} \\
\hline $\mathrm{C}$ & $0.700 \mathrm{~g}$ & $1.676 \mathrm{f}$ & $2.122 \mathrm{~cd}$ & $2.454 \mathrm{a}$ & $1.738 \mathrm{~A}$ \\
\hline $\mathrm{AA}+\mathrm{AN}$ & $0.750 \mathrm{~g}$ & $1.666 \mathrm{f}$ & $2.246 \mathrm{bc}$ & $2.052 \mathrm{~d}$ & $1.678 \mathrm{~A}$ \\
\hline AA & $0.851 \mathrm{~g}$ & 1.825 ef & $1.995 \mathrm{de}$ & $2.404 \mathrm{ab}$ & $1.769 \mathrm{~A}$ \\
\hline \multirow[t]{2}{*}{ Mean } & $0.767 \mathrm{D}$ & $1.722 \mathrm{C}$ & $2.121 \mathrm{~B}$ & $2.303 \mathrm{~A}$ & \\
\hline & \multicolumn{5}{|c|}{2013} \\
\hline $\mathrm{C}$ & $2.042 \mathrm{e}$ & $2.612 \mathrm{~b}-\mathrm{d}$ & $2.764 \mathrm{bc}$ & $3.960 \mathrm{a}$ & $2.844 \mathrm{~A}$ \\
\hline $\mathrm{AA}+\mathrm{AN}$ & $2.235 \mathrm{de}$ & $2.996 \mathrm{~b}$ & $3.059 \mathrm{~b}$ & $3.909 \mathrm{a}$ & $3.050 \mathrm{~A}$ \\
\hline AA & $2.265 \mathrm{c}-\mathrm{e}$ & $3.054 \mathrm{~b}$ & $2.942 \mathrm{~b}$ & $3.875 \mathrm{a}$ & $3.034 \mathrm{~A}$ \\
\hline \multirow[t]{3}{*}{ Mean } & $2.180 \mathrm{C}$ & $2.888 \mathrm{~B}$ & $2.922 \mathrm{~B}$ & $3.914 \mathrm{~A}$ & \\
\hline & \multicolumn{5}{|c|}{ Sinapic acid $\left(\mathrm{mg} 100 \mathrm{~g}^{-1} \mathrm{FW}\right)$} \\
\hline & \multicolumn{5}{|c|}{2012} \\
\hline $\mathrm{C}$ & $1.246 \mathrm{e}$ & $2.117 \mathrm{c}$ & $2.201 \mathrm{bc}$ & $2.207 \mathrm{a}-\mathrm{c}$ & $1.942 \mathrm{~B}$ \\
\hline $\mathrm{AA}+\mathrm{AN}$ & $1.767 \mathrm{~d}$ & $2.249 \mathrm{a}-\mathrm{c}$ & $2.338 \mathrm{a}-\mathrm{c}$ & $2.393 \mathrm{a}-\mathrm{c}$ & $2.187 \mathrm{~A}$ \\
\hline AA & $1.395 \mathrm{e}$ & $2.501 \mathrm{a}$ & $2.356 \mathrm{a}-\mathrm{c}$ & $2.419 \mathrm{ab}$ & $2.167 \mathrm{~A}$ \\
\hline \multirow[t]{2}{*}{ Mean } & $1.469 \mathrm{~B}$ & $2.289 \mathrm{~A}$ & $2.298 \mathrm{~A}$ & $2.339 \mathrm{~A}$ & \\
\hline & \multicolumn{5}{|c|}{2013} \\
\hline $\mathrm{C}$ & 1.799 ef & 1.767 ef & $2.330 \mathrm{~b}-\mathrm{d}$ & $2.131 \mathrm{~b}-\mathrm{e}$ & $2.007 \mathrm{~B}$ \\
\hline $\mathrm{AA}+\mathrm{AN}$ & $1.609 \mathrm{f}$ & $1.768 \mathrm{ef}$ & $2.070 \mathrm{c}-\mathrm{f}$ & $2.494 \mathrm{bc}$ & $1.985 \mathrm{~B}$ \\
\hline AA & 1.728 ef & $1.946 \mathrm{~d}-\mathrm{f}$ & $2.547 \mathrm{ab}$ & $2.961 \mathrm{a}$ & $2.295 \mathrm{~A}$ \\
\hline Mean & $1.712 \mathrm{~B}$ & $1.827 \mathrm{~B}$ & $2.315 \mathrm{~A}$ & $2.529 \mathrm{~A}$ & \\
\hline
\end{tabular}

C - control, AA - amino acids, AN - Ascophyllum nodosum filtrate

*Values marked with the same letter in each column do not differ significantly at $p<0.05$

**Values marked with the same capital letter do not differ significantly at $p<0.05$ 
5 cultivars, but no significant changes were observed in the remaining two cultivars.

In the present study, the concentration of kaempferol in broccoli heads was 3-4 times higher than that of quercetin. This is consistent with the results of the research conducted by GliszczyńskaŚwigło et al. (2007), Kałużewicz et al. (2016) and Koh et al. (2009). In contrast, Bahorun et al. (2004) observed that the concentration of quercetin was 5 times higher than that of kaempferol.

In the present study, it was also found that the application of the biostimulants had led to a higher quercetin content (Tabs 2 and 4). An increased level of kaempferol was found only in the second year of the study after the AA treatment. The concentrations of both of these flavonols increased with the duration of storage, which is consistent with the results of Winkler et al. (2007). Those authors had observed that after a week of storing broccoli at $1{ }^{\circ} \mathrm{C}$, the quercetin content increased by $45 \%$ and that of kaempferol by approximately $11 \%$.

Hydroxycinnamic acids are the most common phenolic acids in plant tissues (Herrmann 1989). This group comprises caffeic acid, chlorogenic acid (caffeic and quinic acid esters), carboxylic acid, ferulic acid and sinapic acid.

The biostimulants caused a significant increase in the concentration of sinapic and caffeic acids. However, no significant effect of the biostimulants on ferulic acid content was found (Tab. 5). In fresh broccoli heads, a significantly higher level of caffeic acid was observed after the application of AA compared to the control treatment only in the first year of the study. This trend was also evident after the first, second and third week of storage. A significant increase in caffeic acid content following the application of biostimulants had also been observed by Ertani et al. (2014). In the first year of our study, the sinapic acid content in fresh broccoli heads was approximately $30 \%$ higher after the AA + AN treatment than in the control plants. However, no significant effect was found in the second year.

The concentrations of all the tested phenolic acids increased with the duration of storage in both the control plants and the plants treated with the biostimulants. An increase in the hydroxycinnamic acid content during broccoli storage had also been reported by Starzyńska et al. (2003). This trend was also confirmed by the research by Duarte-Sierra et al. (2017). Those authors observed that during storage for 14 days at $4^{\circ} \mathrm{C}$ there was an increase in the hydroxycinnamic acid content. The opposite results had been obtained by Fernández-León et al. (2013) after three weeks of storage at $1-2^{\circ} \mathrm{C}$. They found that the amounts of phenolic acids, including the sinapic acid content, decreased by approximately $14 \%$.

Our study confirms the significant effect of both biostimulants on the total phenolic content, with a higher value obtained using AA alone. Quercetin content increased in both years after the use of AA, and in the first year after the application of AA + AN. The use of AA resulted in an increase in sinapic acid content in both years, while in the first year this increase also occurred after the combined use of AA + AN. The level of caffeic acid was higher only in the first year of the study in fresh heads of the plants treated with AA during the vegetation period, and after three weeks of storage after treatment both with AA and with AA + AN.

\section{CONCLUSIONS}

1. The applied biostimulants caused a significant increase in the total phenolic content, as well as in the amounts of sinapic acid and quercetin.

2. The levels of all the phenolic compounds analyzed in broccoli heads increased with the duration of storage in both the treated and untreated plants.

\section{AUTHOR CONTRIBUTIONS}

All of the authors contributed to all aspects of this manuscript, including the development of the ideas, manuscript writing, revisions and joint responsibility for the content.

\section{CONFLICT OF INTEREST}

Authors declare no conflict of interest.

\section{REFERENCES}

BadeŁek E., Kosson R., Adamicki F., 2013. The effect of storage in controlled atmosphere on the quality and health-promoting components of broccoli (Brassica oleracea var. italica). Veg. Crops Res. Bull. 77: 89-100.

Bahorun T., Luximon-Ramma A., Crozier A., Aruoma O.I., 2004. Total phenol, flavonoid, proanthocyanidin and vitamin $\mathrm{C}$ levels and antioxidant activities of Mauritian vegetables. J. Sci. Food Agric. 84: 1553-1561.

Balouchi Z., Peyvast G.A., Ghasemnezhad M., SAADATIAN M., 2011. Changes of antioxidant compounds of broccoli (Brassica oleracea L. var. 
italica) during storage at low and high temperatures. South-west. J. Hortic. Biol. Environ. 2: 193-212.

Borowiak K., GąSEcka M., MleczeK M., DĄBRowsKi J., Chadzinikolau T., Magdziak Z., Goliński P., Rutkowski P., Kozubik T., 2015. Photosynthetic activity in relation to chlorophylls, carbohydrates, phenolics and growth of a hybrid Salix purpurea $\times$ triandra $\times$ viminalis 2 at various $\mathrm{Zn}$ concentrations. Acta Physiol. Plant. 37(8): 155.

Carvalho M.E.A., Castro P.R.C., Novembre A.D.C., Chamma H.M.C.P., 2013. Seaweed extract improves the vigor and provides the rapid emergence of dry bean seeds. Am.-Eurasian Agric. Environ. Sci. 13: 1104-1107.

Conversa G., Bonasia A., Lazzizera C., Elia A., 2013. Changes in biochemical and qualitative properties in fresh-cut broccoli genotypes during storage. Acta Hort. 1005: 641-647.

Dobromilska R., Gubarewicz K., 2008. Influence of Bio-algeen S90 on the yield and quality of small-sized tomato. In: Biostimulators in Modern Agriculture. Solanaceous crops. Z.T. Dąbrowski (Ed.), Wieś Jutra, Warszawa: 7-12.

DU JARdin P., 2015. Plant biostimulants: Definition, concept, main categories and regulation. Sci. Hortic. 196: 3-14.

Duarte-Sierra A., Forney Ch. F., Michaud D., Angers P., Arul J., 2017. Influence of hermetic heat treatment on quality and phytochemical compounds of broccoli florets during storage. Postharv. Biol. Technol. 128: 44-53.

Elansary H.O., Skalicka-Woźniak K., King I.W., 2016. Enhancing stress growth traits as well as phytochemical and antioxidant contents of Spiraea and Pittosporum under seaweed extract treatments. Plant Physiol. Biochem. 105: 310-320.

Ertani A., Pizzeghello D., Francioso O., Sambo P., Sanchez-Cortes S., Nardi S., 2014. Capsicum chinensis L. growth and nutraceutical properties are enhanced by biostimulants in a long-term period: chemical and metabolomics approaches. Front. Plant Sci. 5: 1-12.

Ertani A., Schiavon M., Altissimo A., Franceschi C., NARdi S., 2011. Phenol-containing organic substances stimulate phenylpropanoid metabolism in Zea mays. J. Plant Nutr. Soil Sci. 174: 496-503.

Ertani A., Schiavon M., Muscolo A., Nardi S., 2013. Alfalfa plant-derived biostimulant stimulates shortterm growth of salt stressed Zea mays L. plants. Plant Soil 364: 145-158

Fan D., Hodges D.M., Critchley T., Prithiviraj B., 2013. A commercial extract of brown macroalga (Ascophyllum nodosum) affects yield and the nutritional quality of spinach in vitro. Commun. Soil Sci. Plant Anal. 44: 1873-1884.

Fan D., Hodges D.M., Zhang J., Kirby C.W., Ji X., Locke S.J., Critchley A.T., Prithiviraj B., 2011. Commercial extract of the brown seaweed
Ascophyllum nodosum enhances phenolic antioxidant content of spinach (Spinacia oleracea L.) which protects Caenorhabditis elegans against oxidative and thermal stress. Food Chem. 124: 195-202.

FernándeZ-León M.F., FERnÁndeZ-León A.M., Lozano M., Ayuso M.C., González- Gómez D., 2013. Different postharvest strategies to preserve broccoli quality during storage and shelf life: controlled atmosphere and 1-MCP. Food Chem. 138: 564-573.

Gajewski M., Gos K., Bobruk J., 2008. The influence of Goëmar Goteo biostymulator on yield and quality of two Chinese cabbage cultivars. In: Biostimulators in Modern Agriculture. Vegetable Crops. Z.T. Dąbrowski (Ed.), Wieś Jutra, Warszawa: 21-27.

Gąsecka M., Mleczek M., Siwulski M., Niedzielski P., Kozak L., 2015. The effect of selenium on phenolics and flavonoids in selected edible white rot fungi. LWT 63: 726-731.

GLisZCZYŃSKA-ŚWigŁo A., KAŁUŻEWICZ A., LEMAŃSKA K., Knaflewski M., Tyrakowska B., 2007. The effect of solar radiation on the flavonol content in broccoli inflorescence. Food Chem. 100: 241-245.

Grabowska A., Kunicki E., SęKara A., Kalisz A., JezDinský A., Gintrowicz K., 2015. The effect of biostimulants on the quality parameters of tomato grown for the processing industry. Agrochimica 59: 203-215.

Guo R., Yuan G., Wang Q., 2011. Effect of sucrose and mannitol on the accumulation of health-promoting compounds and the activity of metabolic enzymes in broccoli sprouts. Sci. Hortic. 128:159-165.

GURAV R.G., JADHAV J.P., 2013. A novel source of biofertilizer from feather biomass for banana cultivation. Environ. Sci. Pollut. Res. Int. 20: 45324539.

Hasperué J.H., Lemoine L., Vicente A.R., Chaves A.R., Martínez G. A., 2015. Postharvest senescence of florets from primary and secondary broccoli inflorescences. Postharv. Biol. Technol. 104: 42-47.

HerrmanN K., 1989. Occurrence and content of hydroxycinnamic acid and hydroxybenzoic acid compounds in foods. Crit. Rev. Food. Sci. Nutr. 28: 315-347.

Holdt S.L., KraAn S., 2011. Bioactive compounds in seaweed: functional food applications and legislation. J. Appl. Phycol. 23: 543-597

Hong D.D., Hein H.M., Son P.N., 2007. Seaweeds from Vietnam used for functional food, medicine and biofertilizer. J. Appl. Phycol. 19: 817-826.

JACOBO-VelázQUez D.A., Martínez-Hernández G.B., Rodríguez S.C., CaO C.M., Cisneros-Zevallos L., 2011. Plants as biofactories: physiological role of reactive oxygen species on the accumulation of phenolic antioxidants in carrot tissue under wounding and hyperoxia stress. J. Agric. Food Chem. 59: 6583-6593. 
KaŁuŻewicz A., GLisZCZYŃSKA-ŚwigŁo A., KLIMCZAK I., Lisiecka J., Tyrakowska B., Knaflewski M., 2012. The Influence of short-term storage on the content of flavonoids and vitamin $\mathrm{C}$ in broccoli. Eur. J. Hortic. Sci. 77: 137-143.

KaŁUŻewicz A., LisiecKa J., GĄSECKA M., WaśKIEWICZ A., Krzesiński W., Spiżewski T., FrąszczaK B., 2016. Changes in composition of phenolic compounds and tocopherols in broccoli heads during short-term storage. ŻYWNOŚĆ. Nauka. Technologia. Jakość 3: 127-139.

Klimov S.V., Burakhanova E.A., Dubinina I.M., Alieva G.P., SaĹnikova E.B., Olenichenko N.A., Zagoskina N.V., Trunova T.I., 2008. Suppression of the source activity affects carbon distribution and frost hardiness of vegetating winter wheat plants. Russ. J. Plant Physiol. 55: 308-314.

Koh E., Wimalasiri K.M.S., Chassy A.W., Mitchell A.E., 2009. Content of ascorbic acid, quercetin, kaempferol and total phenolics in commercial broccoli. J. Food Compos. Anal. 22: 637-643.

KowalczyK K., Zielony T., GaJewsKi M., 2008. Effect of Aminoplant and Asahi on yield and quality of lettuce grown on rockwool. In: Biostimulators in Modern Agriculture. Vegetable Crops. Z.T. Dąbrowski (Ed.), Wieś Jutra, Warszawa: 35-43.

Leja M., Mareczek A., Starzyńska A., Rożek S., 2001. Antioxidant ability of broccoli flower buds during short-term storage. Food Chem. 72: 219-222.

Lola-Luz T., Hennequart F., Gaffney M., 2013. Enhancement of phenolic and flavonoid compounds in cabbage (Brassica oleraceae) following application of commercial seaweed ex-tracts of the brown seaweed (Ascophyllum nodosum). Agric. Food Sci. 22: 288-295.

Lola-Luz T., Hennequart F., Gaffney M., 2014. Effect on yield total phenolic, total flavonoid and total isothiocyanate content of two broccoli cultivars (Brassica oleraceae var. italica) following the application of a commercial brown seaweed extract (Ascophyllum nodosum). Agric. Food Sci. 23: 28-37.

Mølmann J.A., Steindal A.L., Bengtsson G.B., SeljÅSen R., Lea P., Skaret J., Johansen T.J., 2015. Effects of temperature and photoperiod on sensory quality and contents of glucosinolates, flavonols and vitamin C in broccoli florets. Food Chem. 172: 47-55.

Nardi S., Pizzeghello D., Schiavon M., Ertani A., 2016. Plant biostimulants: physiological responses induced by protein hydrolyzed-based products and humic substances in plant metabolism. Sci. Agric. 73(1): 18-23.

PoDSĘDEK A., 2007. Natural antioxidants and antioxidant capacity of Brassica vegetables: A review. LWT 40: $1-11$.

Porras-Baclayon D., Matsui T., Haruo S., Kosugi Y., 2007. Changes in activity and gene expression of phenylalanine ammonia-lyase in broccoli branchlets during early postharvest senescence. J. Biol. Sci. 7: 614-619.

Prior R.L., CAO G., 2000: Flavonoids: diet and health relationships. Nutr. Clin. Care 3: 279-288.

Rayorath P., Benkel B., Hodges D.M., Allan-Wojtas P., MacKinnon S., Critchley A.T., Prithiviraj B., 2009. Lipophilic components of the brown seaweed, Ascophyllum nodosum, enhance freezing tolerance in Arabidopsis thaliana. Planta 230: 135-147.

Reed R.H., DAvison I.R., ChudeK J.A., Foster R., 1985. The osmotic role of mannitol in the Phaeophyta: an appraisal. Phycologia 24: 35-47.

Serrano M., Martinez-Romero D., Guillén F., Castillo S., D. Valero D., 2006. Maintenance of broccoli quality and functional properties during cold storage as affected by modified atmosphere packaging. Postharv. Biol. Technol. 39: 61-68.

Shehata S.M., Abdel-Azem H.S., El-Yazied A.A., EL-GiZAWY A.M., 2011. Effect of foliar spraying with amino acids and seaweed extract on growth chemical constitutes, yield and its quality of celeriac plant. Europ. J. Sci. Res. 58(2): 257-265.

Singleton V.L., Rossi J.A., 1965. Colorimetry of total phenolics witch phosphomolybdic-phosphotungstics acid reagents. Am. J. Enol. Vitic. 16(3): 144-158.

StARZyŃSKa A., LeJA M., MarecZeK A., 2003. Physiological changes in the antioxidant system of broccoli flower buds senescing during short-term storage, related to temperature and packaging. Plant Sci. 165: 1387-1395.

Stirk W., Tarkowská D., Turecová V., Strnad M., Staden, J., 2014. Abscisic acid, gibberellins and brassinosteroids in Kelpak, a commercial seaweed extract made from Ecklonia maxima. J. Appl. Phycol. 26: 561-567

SzczePaneK M., Grzybowski K., 2016. Yield and macronutrient accumulation in grain of spring wheat (Triticum aestivum ssp. vulgare L.) as affected by biostimulant application. Adv. Crop Sci. Tech. 4: 228.

Thirumaran G., Arumugam M., Arumugam R., Anantharaman P., 2009. Effect of seaweed liquid fertilizer on growth and pigment concentration of Abelmoschus esculentus (I) medikus. Am.-Eurasian J. Agron. 2: 57-66.

Ugarte R.A., Sharp G., Moore B., 2006. Changes in the brown seaweed Ascophyllum nodosum (L.) Le Jol. Plant morphology and biomass produced by cutter rake harvests in southern New Brunswick, Canada. J. Appl. Phycol. 18: 351-359.

Vale A.P., Santos J., Brito N.V., Marinho C., Amorim V., Rosa E., Oliveira M.B.P.P., 2015. Effect of refrigerated storage on the bioactive compounds and microbial quality of Brassica oleraceae sprouts. Postharv. Biol. Technol. 109, 120-129.

Vallejo F., Tomas-Barberan F.A., Garcia-Viguera C., 2003. Effect of climatic and sulphur fertilisation conditions, on phenolic compounds and vitamin $\mathrm{C}$, 
in the inflorescences of eight broccoli cultivars. Eur. Food Res. Technol. 216 (5): 395-401.

Valverde J., Reilly K., Villacreces S., Gaffney M., Granta J., Bruntona N., 2015. Variation in bioactive content in broccoli (Brassica oleracea var. italica) grown under conventional and organic production systems. J. Sci. Food Agric. 95: 11631171.

Winkler S., Faragher J., Franz P., Imsic M., Jones R., 2007. Glucoraphanin and flavonoid levels remain stable during simulated transport and marketing of broccoli (Brassica oleracea var. italica) heads. Postharv. Biol. Technol. 43: 89-94.
Zhang D., Hamauzu Y., 2003. Phenolic compounds, ascorbic acid, carotenoids and antioxidant properties of green, red and yellow bell peppers. J. Food Agric. Environ. 1: 22-27.

Zodape S.T., Gupta A., Bhandari S.C., Rawat U.S., Cahudhary D.R., Eswaran K., Chikara J., 2011. Foliar application of seaweed sap as biostimulant for enhancement of yield and yield quality of tomato (Lycopersicon esculentum Mill.). J. Sci. Ind. Res. 70: 215-219.

Received July 12, 2017; accepted November 17, 2017 